\title{
Collective transnational bargaining: practical implementation experiences from European Works Councils in Spain*
}

\author{
LUIS GoRdo GonZÁLEZ \\ Assistant Professor of Labour and Social Security Law \\ Universidad Autónoma de Madrid
}

Recibido: 10.6 .2018

Aceptado: 7.7.2018

DOI: https://doi.org/10.20318/sllerj.2018.4435

\begin{abstract}
Council Directives 94/45/EC and 2009/38/EC impose transnational collective bargaining in Community-scale undertakings so as to create procedures for informing and consulting employees in said undertakings. More than twenty years after the first Directive was passed, this article examines the agreements reached by European-scale companies with headquarters in Spain and tries to construct a typical model for European Works Councils among companies in Spain.
\end{abstract}

Keywords: European Works Council, EWC, collective transnational bargaining.

\section{Introduction}

The first European experiences with regulating workers' transnational representation dates back to the 1980s. These initial practices, which were developed in France and Germany as a result of the internationalization of their companies, ${ }^{1}$ extended worker representation to the workforce in other States, using the regulations for determining workers' representation in company groups on the national scale.

The French and German initiatives encouraged debate in the European Union, which, after a first attempt at a Directive (the Vredeling proposal of 20 October, $1980^{2}$ ), finally passed Council Directive 94/45/ EC of 22 September on the establishment of a European Works Council or a procedure in Community-

\footnotetext{
* This article forms part of the research project "El dialogo social en un derecho del trabajo para la recuperación: competitividad empresarial y cohesión social” (DER2015-64676-C2-2-P).

${ }^{1}$ In 1983, one year after the second Auroux Law came into force in France, the transnational company Saint-Gobain informally extended its group works council to workers in other workplaces located in other States. The companies BSN, Bull and Scansped helped consolidate this process between 1984 and 1989. However, in 1985 the company Thomson constituted what is considered to be the first European Works Council. Later would come councils at Volkswagen, with the German ID Metall union, and that of ELF Aquitaine, through an agreement with French unions. Regarding the evolution of this first phase of European Works Councils, see: KÖLER, Holm-Detlev, GONZÁLEZ BEGEGA, Sergio, “Hacia un sistema de relaciones industriales europeo? La experiencia de los Comités de Empresa Europeos (CEUs)", in Cuadernos de Relaciones Laborales, no. 1, 2004, p. 9 to 10; BOGONI, Milena, El Comité de Empresa Europeo, Albacete, Bomarzo, 2010, p. 9; ANTONELLO BENITES, Flavio, "Los Comités de Empresa Europeos y los cambios organizativos en los centros de trabajo", in AA.VV. (Coord. Rodríguez Piñero-Royo, Miguel C.), El empleador en el derecho del trabajo. XVI Jornadas Universitarias Andaluzas de Derecho del Trabajo y Relaciones Laborales, Tecnos/Consejo Andaluz de Relaciones Laborales, Madrid, 1999, p. 257. For an in-depth analysis of the European Works Council at Saint-Gobain, see: GONZÁLEZ BEGEGA, Sergio, Empresa transnacional y nuevas relaciones laborales: La experiencia de los comités de empresa europeos, Catarata, Madrid, 2011, p.197-234.

${ }^{2}$ Draft Directive dated 24 October 1980, on procedures for informing and consulting employees, known as the "Vredeling Directive" in honour of the Dutch Commissioner who proposed it. (OJ no. C 297, of 15.11.80, p. 3). The aim of this proposal
} 
scale undertakings and Community-scale groups of undertakings for the purposes of informing and consulting employees. This regulation would later be updated by Council Directive 2009/38/EC, of 6 May. ${ }^{3}$

As is well known, both Directive 94/45 and the subsequent Directive 2009/38/EC stipulate that Community-scale undertakings must approve mechanisms for informing and consulting their workers, ${ }^{4}$ either through specific procedures or through the creation of a European Works Council (hereinafter EWC).

European regulations are characterised by giving a central role to collective autonomy and to the member States: the central role given to collective autonomy is because national and European regulations will only be applied if no agreement can be reached between the parties. The importance of national legislation arises from the fact that it determines important issues such as the concept of worker, the formula used to calculate the number of workers, the guarantees for worker representatives, Council operation costs, or sanctions for non-compliance. ${ }^{5}$ Thus, we can say that the Directives have attempted to establish a minimum baseline that can be improved upon by agreements between the parties or by national legislation.

Analysing the success or failure of the implementation of information and consultation processes in Europe is a difficult task given that, although unions have demanded the creation of a public Community registry on several occasions, we do not have official data on a European level regarding collective bargaining processes that lead to the approval of ad hoc information and consultation processes or an EWC.

The only unofficial data is provided by the European Trade Union Institution (hereinafter ETUI) database. ${ }^{6}$ The problem with this database is that, precisely due to its unofficial nature, it may contain agreements that have since been terminated by one of the parties, or may omit current agreements if the ETUI is not aware of their approval. ${ }^{7}$

While this data must be considered with a certain degree of caution, it may be able to show how information and consultation processes are evolving in Europe.

At this time, 1,127 companies have an agreement in force that approves the creation of an EWC, ${ }^{8}$ which represents just over $50 \%$ of the 2,492 Community-scale undertakings identified by the ETUI. The

was to achieve coordination between the national legislatures so as to limit or prevent cases of social dumping. When blocked by business, a new draft Directive, known as "Vredeling-Richard", was presented on 13 July, 1983. This draft was much less ambitious, and did not have the support of management (the modified proposal was published in OJ no. C 217, of 12/12/1983, p. 3).

${ }^{3}$ The modifications made under Directive 2009/38/EC have been, without a doubt, the most significant. However, Directive 94/45/EC was also modified by Directive 97/74/EC, of 15 December, 1997 (OJ L 10, of 16 January 1998), which expanded the legal scheme set out in Directive 94/45 to include the United Kingdom of Great Britain and Northern Ireland, States which had been excluded from application until that time.

${ }^{4}$ Determining whether a European undertaking or group of undertakings has a Community scale is not without difficulties. However, as the aim of this article is not to provide a detailed analysis of the problems arising from determining European scale, we can succinctly summarize that Community-scale undertakings are those undertakings or groups of undertakings that employ 1,000 workers or more across all member States and which provide employment for at least 150 or more workers in two group workplaces or companies located in two different States. Furthermore, in order to consider that several undertakings are related within one group, one of these undertakings must exercise a position of control over the others. An undertaking exercises control over another when it has developed a dominating influence, for example, for reasons of ownership, financial participation or articles of association. Unless otherwise proven, it shall be assumed that one undertaking exercises control over another when: it holds the majority of the undertaking's subscribed capital, it has the majority of the votes corresponding to the shares issued by the undertaking, or it can name more than half of the members of the undertaking's board of directors or management board. If, in accordance with the above rules, several undertakings could be said to exercise control over another, it will be assumed, unless otherwise proven, that the undertaking that exercises control over the group is that which can name more than half of the members of the board of directors or management board. Control may be exercised directly or indirectly, through other controlled companies.

${ }^{5}$ This double subordination has been defined graphically as vertical subordination (European legislation - national legislation) and horizontal subordination (European legislation - agreements between the parties), see: the report prepared by the Economic and Social Committee (ESC) on the "Draft Law on workers' rights to information and consultation in Community-scale undertakings and groups of undertakings" (EESC plenary session of 24 January 1996), p. 6.

${ }^{6}$ The datebase could be found at: http://www.ewcdb.eu.

${ }^{7}$ One of the changes included in Directive 2009/38/EC was that the parties must notify European workers' and employer organizations of the start and composition of bargaining commissions (Directive art. 5.2.c). However, this obligation is limited to formally communicating the beginning of negotiations, but not the result. Furthermore, it should be kept in mind that negotiations can last for a maximum of three years and thus, over such a long period of time, the conclusion of the negotiations may go unnoticed by the ETUI.

${ }^{8}$ Barely $1 \%$ of the total has chosen to constitute specific agreements instead of an EWC, which is why we will generally speak about agreements constituting an EWC. 
majority of these agreements have been reached in the metal and chemical sectors, which is not surprising given that these sectors have a strong history of union activity and are characterised by large-scale companies. If we look at EWCs according to the headquarters' country of origin, it is also not surprising to see that the countries with the greatest number of EWCs are, in decreasing order: Germany, USA, France, and the UK. They are, clearly, countries with a large number of Community-scale undertakings.

\section{The Spanish model of European Works Council}

The content of Directive 94/45 was implemented in Spain through Law 10/1997, of 24 April, regarding workers' rights to information and consultation in Community-scale companies and groups of companies. ${ }^{9}$ From that time on, representatives for workers and management in European-scale companies with their headquarters in Spain or with headquarters in a non-EU member state, but designating Spain as their headquarters in the EU, were able to create an EWC in accordance with Community regulations.

Of the 56 Community-scale companies in Spain identified by the ETUI, only fourteen have reached agreements to incorporate an EWC that have been published in the Official State Gazette (BOE, using its acronym in Spanish). ${ }^{10}$ Without a doubt, the results are disappointing. Such a small number of agreements may be explained by the low number of Community-scale companies in Spain. Spanish companies tend to internationalise their activity towards Latin America due to reasons of cultural affinity. However, it does not explain why large Spanish companies with offices in European States have taken so long to constitute an EWC. Perhaps it is due to the mistrust and lack of knowledge regarding this institution. ${ }^{11}$

Of the fourteen agreements published in the BOE, the first was approved almost at the same time the Directive was implemented, signed by Repsol on 16 July $1997^{12}$ for a period of two years and to be automatically renewed at the end of each period. The creation of this EWC is of particular interest, as it is the only one to be included within a Spanish framework agreement. This means that this agreement was only negotiated by the most representative unions on the national level, who also have majority representation in the different Spanish works councils. Section 17 of this agreement contains regulations regarding information and consultation procedures on the European level.

\footnotetext{
${ }^{9}$ Law 10/1997, of 24 April, was subsequently amended by Law 44/1999, of 29 November, so as to adapt its content to the extension of Directive 94/45/EC to the United Kingdom; and again by Law 10/2011, of 19 May, to incorporate the amendments set out in Directive 2009/38/EC.

${ }^{10}$ In the implementation of Directives 94/45 and 2009/38/EC, Spanish legislators introduced an additional requirement. Law 10/1997 of 24 April, article 13, referring to article 90 of the Workers' Statute, establishes that the agreements must be presented to the competent labour authority for their registration, filing, and publication in the BOE. This requirement is fully consistent with the regulations regarding Spain's collective agreements for general efficiency or ergea omnes. However, four companies have reached agreements to constitute an EWC which have not been published in the BOE: Grupo Gestamp (29 January 2015), Grupo Ferroatlántica (4 February 2014), Grupo AMADEUS (25 May 2013) and Grupo Campofrío (4 March 2009). Publishing the collective agreements, as established in article 90 of the Workers' Statute, aims to guarantee that general knowledge of the terms agreed upon by the parties is made available to third parties, without official publication depriving the agreement of effectiveness. Several legal rulings have been made along these lines: Ruling of the National Court of Spain dated 29 October 1998 (Proc. 77/1998) Court Opinion no. 4; Ruling of the High Court of Justice of Madrid dated 14 September 2012 (R. 4089/2012) Court Opinion no. 25; Ruling of the High Court of Justice of Asturias dated 3 June 2003 (R. 2968/2001) Court Opinion no. 2.

${ }^{11}$ Other factors that may explain low numbers of EWCs in Spain are: the structure of Spanish business, with a high number of SMEs that have fewer than the 1,000 worker cut-off established by the Directive; the strong reticence of Spanish management to give up, even indirectly, some control over its companies to the workers' representatives; and the lack of tradition and initiative of Spanish unions in defending the creation of EWCs in Spain. While these factors seem to be confirmed by the actors involved in EWC constitution themselves (unions, management, and institutional representatives), others, such as the economic cost of implementing this measure, are not supported by empirical data. In this regard, see: ALBALATE, Joaquín Juan, "La implantación de los Comités de Empresa Europeos en España”, en Revista Española de Investigaciones Sociológicas, núm. 124, 2008, pp. 177-207, p. 193 et seq.

${ }^{12}$ Agreement published in the BOE on 10 December 1997 (BOE 295). Several updates have been published since then: Agreement dated 12 November 2001 (BOE of 29 November, no. 286) and Agreement dated 30 May 2011 (BOE of 18 July, no. 171).
} 
Later came agreements at GE Power Controls Ibérica, ${ }^{13}$ Praxair Group, ${ }^{14}$ Tafisa Group,,${ }^{15}$ Altadis,${ }^{16}$ Banco Bilbao Vizcaya Argentaria Group, ${ }^{17}$ Saica Group, ${ }^{18}$ Santander Group, ${ }^{19}$ AXA Group,${ }^{20}$ Roca Corporación Empresarial, ${ }^{21}$ Abertis Group, ${ }^{22}$ and, the most recent, Prosegur Group, ${ }^{23}$ Schreiber Foods ${ }^{24}$ and, the most recent, IAG International Group..$^{25}$ Additionally, six other EWCs have been constituted but not published in the BOE at Gestamp, Ferroatlántica, Amadeus, Campofrío Groups., NH Hoteles and CocaCola Iberian Partners. ${ }^{26}$

Each of these agreements was influenced by the context in which it was negotiated, and by each company's own business culture. This means that some have incorporated interesting solutions or alternatives to problems related to articulating worker representation on a European scale, while others have simply limited themselves to transcribing the content of the Directives and Law 10/1997. However, by analysing all of these agreements, some general conclusions can be drawn and we can even formulate a general paradigm of Spanish EWCs.

The analysis of the agreements has taken into consideration twelve variables: the type of EWC; the number of representatives who comprise it; the criteria for distributing representation among the different States where the company operates; the existence (or lack thereof) of a select committee; the formula chosen for designating representatives to form part of the EWC; the requirements that representatives must meet to be on the EWC; the appointment (or lack thereof) of substitutes; the possibility of the company's management determining representation beforehand; the EWC's operational costs that are to be assumed by the company; the number and types of meetings to be held; if there is a confidentiality obligation; and, finally, the topics subject to information and consultation. These variables will allow us to perform an indepth examination of the reality of EWCs in Spain and determine their common characteristics.

\section{Content and characteristics of the EWC constitution agreements in Spain}

In accordance with the methodology described above, we will examine below the agreements subject to Spanish law, both those published in the Official State Gazette and those not. ${ }^{27}$

\footnotetext{
${ }^{13}$ Agreement dated 26 November 1999 (BOE of 21 December, no. 304). The aforementioned agreement is no longer in effect as a new regulation was agreed upon between the workers' representatives and headquarters, now located in Hungary. The group, now called GE Consumer \& Industrial, updated the EWC for the last time on 14 September 2007.

${ }^{14}$ The Praxair Group's headquarters are located in the US. The US parent company designated Praxair Spain as the central office for the purposes of constituting the EWC. The EWC was finally constituted through an agreement dated 4 April 2000 (BOE of 21 June, no. 148). It was then updated through an agreement dated 4 May 2004 (BOE of 1 June, no. 158).

${ }^{15}$ Agreement dated 13 March 2002 (BOE of April 11, 2002, no. 87).

${ }^{16}$ Agreement dated 14 November 2002 (BOE of 10 January 2003, no. 9). This Agreement went out of effect after the acquisition of Altadis by Imperial Tobacco in 2010. The new group that arose from the acquisition renegotiated the information and consultation procedures based on the pre-existing agreement at Imperial Tobacco and created a new agreement, which went into effect on 30 March 2011, effective retroactively from the date of purchase, 14 November 2010. However, as the Altadis agreement was published in the Spanish Official State Gazette and it contains interesting advances compared to other Spanish EWCs, we will analyse this agreement.

${ }^{17}$ Agreement dated 3 June 2004 (BOE of 3 August 2004, no. 186)

${ }^{18}$ Agreement dated 21 June 2004 (BOE of 24 August, no. 204).

${ }^{19}$ Agreement dated 16 March 2005 (BOE of 30 May, no. 128).

${ }^{20}$ Although the AXA Group's central headquarters are located in France, the EWC constitution agreement was published in Spain. Agreement dated 6 October 2005 (BOE of 7 June 2006, no. 135).

${ }^{21}$ Agreement dated 31 October 2000 (BOE of 19 December, no. 303). Subsequently renegotiated via Agreement dated 2 July 2007 (BOE of 3 September, no. 211) and Agreement dated 9 July 2014 (BOE of 18 August, no. 200).

${ }^{22}$ Agreement dated 23 July 2012 (BOE of 21 September, no. 228).

${ }^{23}$ Agreement dated 15 November 2013 (BOE of 23 January 2014, no. 20).

${ }^{24}$ Agreement dated 23 November de 2016 (BOE 30 of December 2016, no. 315).

${ }^{25}$ Agreement dated 27 de April de 2017 (BOE 16 of June 2017, no. 143).

${ }^{26}$ Grupo Gestamp (29 January 2015), Grupo Ferroatlántica (4 February 2014), Grupo AMADEUS (25 May 2013) and Grupo Campofrío (4 March 2009), NH Hoteles (9 October 2015) y Coca-Cola Iberian Parther (25 May 2016). See ETUI database. (http://www.ewcdb.eu/). Last access: June 2018.

${ }^{27}$ It has already been mentioned that publishing the agreement in the BOE is not a requirement for said agreement to be valid (see footnote 10). In that regard, based on this analysis of the EWCs, the agreements' publication in the BOE or lack
} 
a) Type of EWC: The majority of Spanish EWCs have been based on a French model of representation. That is, almost all of the agreements include a mixed composition of company and worker representatives, with the exception of GF Power, Roca, Abertis, Prosegur, Campofrío and Ferroatlántica.

The decision of the parties to choose the French model or the German (EWC comprised solely of workers) is not insignificant, as the French model has more similarities to the dominant representation model in Spain. Those companies with EWCs inspired in the German model, in general, have more complex regulations that provide a greater guarantee in terms of worker representation. On the contrary, those agreements that call for mixed councils have chosen more conventional regulations, which cover the necessary minimum, but whose usefulness is doubtful.

b) Number of representatives: Unlike Spanish companies' national councils, in Community-scale companies the number of worker representatives is small. The number of representatives comprising the EWCs barely exceeds a dozen members on average, in companies where the workforce often exceeds 5,000 workers. ${ }^{28}$ On the contrary, in Spain, for the national works councils, a company with a workforce of 5,000 workers should have a council consisting of 29 representatives; the number of representatives could be as many as 75 for companies with very large workforces. ${ }^{29}$

The average number of representatives on the Spanish EWCs is even far from the minimum of 30 representatives set out in the subsidiary provisions in the Annex of Directive 94/45, to be applied in lieu of an agreement between the parties. The formula that Spanish companies have chosen to use more closely follows the criteria that were set out in the Annex of Directive 2009/38/EC. These criteria stipulate that one representative be chosen per portion of employees employed in that Member State amounting to $10 \%$, or a fraction thereof, of the number of employees employed in the entire workforce. This regulation tacitly reduces representation to a mere dozen representatives ${ }^{30}$.

The significant difference between the number of participants on the national and Community councils may perhaps be explained by the goals of each entity. The national councils are a negotiating entity, designed to serve as a counterweight to the employer's decisions. Whereas the EWCs, in principle, only aim to correctly transmit information and consultations on a transnational level. The nature of this second task, much more limited and simple than the first, is what allows the EWCs to have a smaller number of members. In reality, just one member in each State would be sufficient to communicate Community-level information to the national councils.

thereof does not imply differences in terms of content and characteristics, with one exception: training. While of the published agreements, only five of twelve state that the company will assume the training costs for representatives, in the unpublished agreements the majority (three of four) state that the company will assume said costs. However, this sole difference between the published and unpublished agreements is easier to explain if we keep in mind the date the agreements were adopted. Almost all of the most modern agreements include the representatives' right to training; this can be explained by the fact that as the EWCs have evolved, it has been seen that the representatives require specific technical, legal, and economic training, as well as language training, in order to be able to satisfactorily complete their work. Therefore, the most modern agreements have adapted to this need.

${ }^{28}$ For example, the BBVA group, with more than 32,000 workers, has an EWC consisting of 8 representatives; the Santander group, with more than 68,000 workers, has an EWC with 10 representatives; Prosegur, with more than 17,900 workers, also has a council of 10 workers; Praxair has more than 2,900 workers and its EWC consists of 12 members; Ferroatlántica has a 12-member EWC; Saica, with more than 5,400 workers, has an EWC with 14 representatives; the Abertis group's EWC consists of 17 workers who represent a total of 8,700; the agreement no longer in effect at Altadis provided for 17 representatives for 13,800 workers; the Amadeus group's agreement establishes an EWC with 20 members for a workforce of 6,205; Gestamp's agreement stipulates that 21 members must represent 18,840 workers. As an exception, AXA group's EWC has 50 members to represent a workforce of just over 57,500.

${ }^{29}$ The number of members on the works councils is determined in accordance with the scale set out in article 66.1 of the Workers' Statute: workplaces with more than 3,000 workers shall have 25 council members; 27 representatives for 4,000 workers; 31 for 6,$000 ; 33$ for 7,$000 ; 35$ for 8,000 , etc.

${ }^{30}$ If the EWC had one representative for every $10 \%$, the maximum number of representatives on the council would be 10 . However, since each fraction may also increase the number of council members, it may be the case that a company has small workforces and workplaces in several States, so they would have to choose more than 10 representatives since they had 5\% of their workforce in different States. 
c) Criteria for distributing the number of representatives among the different States: In this case, the Spanish EWC prototype favours proportionality in the distribution of council members.

The agreements perform a proportional distribution using three formulas. Only one agreement, for the company Saica, opts for a purely proportional distribution; that is, dividing the number of representatives by the workforce and assigning transnational representatives based on that calculation. The rest have adopted a proportional distribution based on a scale of the number of workers or a percentage of workers employed in each State. ${ }^{31}$

Proportional distribution makes representation of States with a smaller number of workers difficult; they may not obtain representation on the EWC. This problem does not exist in those agreements that determine the States' representation based on a linear formula, assigning the same number of representatives to all States, or discretionally, ${ }^{32}$ assigning a different number of representatives to each State. However, linear and discretionary amount representation overrepresents States with fewer workers, at the expense of States with larger workforces. ${ }^{33}$

Proportional systems attempt to prevent under- and over-representation by reserving a fixed representation for all States. This minimum representation may be establishing one representative for each State in which the company operates, or setting minimum joint representation for all States that do not reach the first threshold on the distribution scale. ${ }^{34}$

The AXA group's agreement offers an interesting solution somewhere between the others, with the advantages of the two models, a limitation on the number of workers, and a correct articulation of the mechanisms of workforce information and consultation which, although in the minority, should be extended to other agreements. The agreement stipulates that only those States in which the group employs more than 150 workers will have the right to name representatives. For those States that do not reach this cut-off, they have created the figure of indirect representative. That is, a direct representative, elected by another State, is in charge of indirectly informing the workers in another State who do not have representation. The interesting part of this solution is that the agreement itself establishes that these indirect representatives are entitled to meet with the national representatives of the countries that they indirectly represent twice a year. Therefore, this agreement includes effective, directly enactable mechanisms that allow the entire company workforce to be adequately represented.

Lastly, only two agreements have established additional representation for those States in which the company's headquarters is located. Axa's agreement assigns three additional worker representatives to the State where central headquarters is located, ${ }^{35}$ while Abertis' agreement only assigns one. However, while these types of agreements are the exception, it should be noted at this time that they are examples of what should not be done. In proportional agreements, there is no reason that justifies additional representation for the State where the headquarters is located.

\footnotetext{
${ }^{31}$ Agreements that use a distribution based on the percentage of workers: Abertis, Roca, BBVA, Campofrío, Gestamp and Tafisa. On the other hand, agreements that distribute representation based on the number of workers: AXA, Santander, Praxair, Amadeus, Schreiber Foods and IAG International Group.

${ }^{32}$ The agreements made by Prosegur, Altadis, GE Power, Repsol and Ferroatlántica set the number of representatives assigned to each State without referencing any criteria used for the distribution. However, a higher or lower number of representatives seems to coincide with those States in which the company has a higher or lower number of workers employed, or in which the unions are more organised in the company.

${ }^{33}$ This imbalance in favour of States that employ a lower number of workers is diminished in discretionary assignment of representatives. Although not explicitly stated, distribution involving a discretionary number of members from each State for the EWC tends to assign more representatives to States in which more workers are employed and, therefore, establishes a de facto hidden proportional distribution.

${ }^{34}$ Abertis, Gestamp and Roca recognise one representative from each State. BBVA, Tafisa, Praxair and Amadeus recognise one representative from each State that employs at least 100, 100, 40, and 20 workers respectively. Finally, Santander's agreement establishes a scale with a first threshold of 500 workers. In principle, the States in which the group employs fewer workers would not have representation. However, the agreement stipulates that between all of them, they shall designate a common representative.

${ }^{35}$ Despite Axa's central headquarters being located in France, their agreement was published in the Spanish BOE. Therefore, the three additional representatives for the State where the headquarters are located are awarded to France.
} 
d) Select committee: Directive 2009/38/EC included for the first time the provision that the agreements constituting the EWCs could include the creation of a select committee. ${ }^{36}$ The incorporation of this body intended to guarantee that the regular activity of the European Works Councils was coordinated and efficient, and that consultations could be performed as quickly as possible in exceptional circumstances. ${ }^{37}$ The subsidiary requirements set out in the Annex of the Directive stipulate that the select committee should not consist of more than five members. Spanish legislators developed this measure through article 19.2 of Law 10/1997. The subsidiary regulations applicable in Spain establish that if the number of European Works Council members is greater than twelve, they must choose a select committee consisting of three members. This rule seems to be counter-intuitive, as in EWCs with fewer than 12 members it should not be necessary to constitute a select committee.

As this characteristic was incorporated in Directive 2009/38/EC, its presence in the Spanish EWCs is inconsistent. In general, the earlier agreements subject to Directive 94/45 do not include a select committee. ${ }^{38}$ However, the majority of earlier agreements that were later revised and the second-generation agreements, which are subject to the regulations arising from Directive 2009/38/EC, do include this entity. ${ }^{39}$

Five agreements break this general rule: the first-generation agreements made by GE Power, Saica, Axa and Campofrío include the figure of a select committee, even before the EC regulation expressly included it in its articles. This measure was not impossible, as the EC regulation was only of subsidiary application. On the other hand, the second-generation Prosegur agreement does not include a select committee, probably due to the low number of members of the plenary EWC, comprised of just ten members.

Therefore, the majority of the EWCs in Spain have chosen to include this body so as to bolster the effectiveness of transnational worker representation.

e) Choosing EWC representatives: Almost unanimously, the process for choosing representatives for Spanish EWCs refers to the subsidiary regulation in each State. In this way, the workers' representatives, chosen in compliance with the general rules set out in Spain, will be chosen in a second election from among the Spanish representatives on workers' committees, or from among the trade union delegates. The choice will be made by an agreement between those union representations that together make up the majority of the work council or councils and personnel delegates, as applicable, or by majority agreement between said members and delegates. ${ }^{40}$

\footnotetext{
${ }^{36}$ Article 6.2.e of Directive 2009/38/EC: "Without prejudice to the autonomy of the parties, the agreement referred to in paragraph 1 [regarding the implementation of information and consultation procedures in the company] and effected in writing between the central management and the special negotiating body shall determine: [...] (e) where necessary, the composition, the appointment procedure, the functions and the procedural rules of the select committee set up within the European Works Council." Directive 94/45 did not contain any reference to the select committee in its articles, however it did in the subsidiary regulations set out in the Annex of the Directive; these regulations were to be used by States when drawing up their own regulations and by companies that wished to directly apply the Directive's provisions. Section 1.c of the Annex established that if the size of the EWC so justified, a select committee would be elected, consisting of three members maximum.

${ }^{37}$ See Whereas 30 Directive 2009/38/EC.

${ }_{38}$ The select committee is not included in the agreements made by Repsol, Praxair, Altadis, Santander and BBVA.

${ }^{39}$ The Roca agreement (revised first generation), and the Abertis, Amadeus, Gestamp, Tafisa and Ferroatlántica, Scheiber Foods, and IAG Group agreements (second generation) include a select committee.

${ }^{40}$ In Spain, the representatives that should make up the special negotiating body and the European Works Council shall be designated in accordance with those union representations that together make up the majority of the work council or councils and personnel delegates, as applicable, or by majority agreement between said members and delegates. Substitute representatives will be chosen in the same manner in the case of resignations or loss of condition of national worker representatives (art. 27 Law 10/1997). Other States, on the other hand, have chosen alternative methods. For example, in Germany, representatives shall be designated by the Central Workers' Committee [what in Spain would be called an Intercentres Committee] in Community-scale companies or by the combined committee in European-scale groups of companies; if a combined committee does not exist, the representatives shall be designated through a joint meeting of the central committees or of the work councils if there are no central committees, which will be called by the Chairman of the committee of the company that employs the largest number of workers. If a work council were not represented in the central committees, their Chairman would also be invited to this meeting ( $\$ 11$ Gesetz über Europäische Betriebsräte). In Italy, the designation will be performed by unions that have signed the national collective agreement that applies to the European-scale company or group of companies and the
} 
Interestingly, only one agreement does not follow this general rule: the Abertis agreement. This agreement states that the Spanish representatives shall be elected by the most representative union organisations in the Spanish national sphere that have a minimum of $20 \%$ of the representation in the Abertis group, from among those members elected to the work council, the personnel delegates or the union representatives. ${ }^{41}$

The Campofrío and IAG Group agreements also include an exception to the general rule, although of less importance than the exception in the Abertis agreement in terms of union participation. This agreement states that the representatives shall be chosen by the representatives on the national works councils and by union organisations established in the company. If there is no agreement in place, the representatives will be chosen in proportion to the distribution of the national councils, or by the union organisation with the greatest representation in the sector in that State if there are no works councils. The IAG agreement asserts that the national workers' representatives have to elect the European representatives. If there are no national representatives, it is the workers who have to elect these European representatives.

So, the Campofrío and IAG agreements are exceptions to the general rule and they create a general fixed norm with regards to elections for all States. This fixed norm for regulating the election of workers' representatives helps to stimulate corporate culture within the group and boosts the visibility of the workers' transnational representatives.

These regulations are one of the few examples in which, to a lesser or greater extent, unions are allowed to directly intervene. This general exclusion is due to the fact that European management organisations, despite the unions' demands, refused to give them a more prominent role. This stance has been followed by companies when drawing up their agreements, giving the unions no role or recognition.

f) Representative requirements: Regardless of how the EWC members are chosen, all of the agreements have established that the candidates must be employees at the company or group where the transnational worker representation body is to be established. ${ }^{42}$ However, almost all of the agreements are silent with regards to additional requirements that the workers must meet to be eligible. Therefore, in these cases, each national delegation must respect the regulations in their home State that govern the requirements that workers must meet in order to be elected as representatives by their colleagues.

However, some agreements have included some specific requirements. The agreements for the AXA and Prosegur groups have expressly stipulated that employees must have worked at the company for a minimum of six months in order to be elected to the EWC. With this rule, the companies are extending a requirement from Spanish law, article 69.2 of the Workers' Statute, to all of the States in which the group operates, even if there is no such requirement in these other States. Similarly, the Campofrío group agreement stipulates that an employee must have worked for the company for a year in order to be chosen for the EWC, while Praxair requires two years. The regulations regarding worker requirements to be eligible for the EWC are much stricter at the Tafisa group. Tafisa requires workers who wish to be part of the group's EWC to have worked at group companies continuously for at least three years. By virtue of the collective autonomy that governs the agreement between the parties, the inclusion of a minimum time at the company impedes application of the subsidiary rules in each country.

union confederations in the company or group. When there is no union representation, the union organisations that signed the national collective agreement that applies to the company and the company's central management will come to an agreement over how to create a system that will allow workers to be represented (art. 6 of Italian Legislative Decree no. 74, dated 2 April 2002, regarding all'istituzione di un comitato aziendale europeo o di una procedura per l'informazione e la consultazione dei lavoratori nelle imprese e nei gruppi di imprese di dimensioni comunitarie). In France, the representatives shall be chosen by union organizations from among the workers' representatives in the company or workplaces (arts. L 439-19 Loi $n^{\circ} 96-985 d u$ 12 novembre 1996 relative à l'information et à la consultation des salariés dans les entreprises et les groupes d'entreprises de dimension communautaire, ainsi qu'au développement de la négociation collective).

${ }^{41}$ Representatives from other States shall be chosen by unions or by personnel representation bodies, depending on the laws in each State.

${ }^{42}$ The agreements thus follow the subsidiary rule set out in Art. 17.1 of Law 10/1997. 
Therefore, in the case of Tafisa, Spanish workers must have worked at the company for three years, and not the six months required by Spanish legislation. ${ }^{43}$

g) Substitute representatives: almost all of the agreements provide for the election of substitute representatives for cases in which the original representative cannot fulfil his or her main obligations ${ }^{44}$ which are usually limited to attending the annual EWC meeting.

The figure of a substitute in worker representation bodies is a strange institution in Spanish regulation, but is very useful for a transnational body. Including a substitute is beneficial in a representation model as limited as the EWC. Essentially, the activity of the transnational workers' representatives is limited to the annual meeting with the company's central management. Therefore, if one of the representatives were missing at these meetings, it would endanger the effectiveness of informing and consulting the workers. This situation does not occur in worker representation on a national scale, where the representative's activity is carried out in a less concentrated period of time.

In almost all of the agreements, the substitute's purpose is limited to substituting the main representative in those cases in which he or she cannot perform his or her functions. Thus, we should ask ourselves what requirements the substitutes must meet and what guarantees protect them. Some agreements explicitly require the substitutes to meet the same requirements as the main representatives, but even these agreements are silent on their guarantees. Given the nature of the substitute institution, the most appropriate approach would be to grant them the same guarantees as the main representatives, while they must also meet the same requirements. Otherwise, it could be the case that those who are designated as substitutes, who would be seen as potential transnational representatives for the workers, would not be protected equally.

Only one agreement confers an additional function upon the substitute beyond substituting the main representative. We would like to highlight it as a recommendable practice that should be included in all Spanish agreements. The AXA agreement establishes that for meetings which take place outside of the country in which the headquarters is located, the substitutes may attend the annual meetings held in that State and participate, but not vote. This is a simple way to facilitate coordination between main representatives and substitutes and to strengthen the EWC's activity.

Other agreements only ensure that the substitutes receive copies of the minutes from the meetings. ${ }^{45}$ This obligation is interesting because it means that the substitutes are informed and familiar with all that they need to know in case they one day need to attend a meeting, but it would have been better to allow the substitutes to participate in all the meetings as listeners.

h) Composition of employer representation: it would be expected that in a transnational body created to provide information to workers and seek their opinion, which generally meets annually, that the agreements constituting said bodies would also contain rules or regulations governing the presence of employer representation at these meetings. However, the reality is that, regardless of whether the council follows the French model, with simultaneous worker and employer participation, or whether it follows the German model and consists exclusively of the workers, the agreements do not contain specific rules regarding the composition of the company's managerial representation. The only reference that is generally made in these agreements is that the number of management representatives cannot exceed the number of worker representatives.

Two agreements have included provisions regarding managerial representation, but they are not very ambitious. The Amadeus group ambiguously stipulates that the management shall be represented by members of the management with the appropriate decision-making

\footnotetext{
${ }^{43}$ The eligibility requirements differ from one State to another. For example: Greece requires workers to be at the company for a minimum of two months; Belgium, Austria and Germany require six months; France, the Netherlands, Romania and Luxembourg require at least one year of service. The periods, as well as additional requirements set out by some legislatures, such as the worker's minimum age or type of contract that they must have to be eligible, can be found in a table prepared by the ETUI, see http://www.ewcdb.eu/show pdf.php?document=9963ori EN.pdf [January 2015].

${ }^{44}$ Only the Repsol and Campofrío agreements do not mention this figure.

${ }^{45}$ See Art. 4.2 Schreiber Foods, Agreement SL, 23 of November 2016, (BOE 30 November 2016, No. 315).
} 
and representation level within the company's organisation chart and who are duly authorised. The Ferroatlántica group establishes that the managerial representation will consist of the General Production Manager and/or the Managing Director. The Director may be assisted in all meetings or may delegate his/her presence to three people who he or she considers to be fully authorised to participate in the meeting. Although setting minimum guarantees to regulate the presence of the managerial representation at the EWC is a good approach, the Ferroatlántica group does it in such a broad way that the regulation is essentially meaningless, since it allows the company total freedom in designating their representatives.

In addition to the Ferroatlántica and Amadeus group EWCs, three other exceptions can be mentioned as more suitable formulas that should be adopted by future EWCs. First, the GE Power agreement stipulates that the company's representatives shall be the CEO and the European Director of Human Resources. Both may be substituted, and both may be accompanied by other company employees who have technical knowledge related to the agenda of each meeting. Second, the agreement that regulates Roca's EWC goes even further and states that the managerial representatives shall include, at least, the Group Manager, who will also preside over joint meetings, three members of human resources management, and two members of management who oversee operations in the production or sales departments. Finally, the Schreiber Foods agreement designates the CEO and two Regional Directors of Human Resources as the enterprise representatives. Moreover, the European Director of Human Resources will chair the meetings along with the President of the EWC.

Given the control that the EWC may exercise, it is a very positive step that the company specify which managerial representatives will attend council meetings. This ensures that the meetings will always have sufficient participation and that the management is not making it more difficult for the EWC to receive the appropriate information by sending second- or thirdtier managers to the annual meetings.

i) EWC operational costs: the distribution of the costs associated with the EWC is one of the aspects that should be regulated by the constitution agreements. This may be one area of the agreements where the greatest dissimilarities can be found. However, there may be some overlap.

In Spain, almost all companies' central management assumes the costs of simultaneous interpretation at meetings between worker representatives and central management, and even covers the translation of working documents. However, some agreements limit the number of languages for interpretation/translation. ${ }^{46}$

Furthermore, although when the Directives were being negotiated business organizations did everything in their power to avoid including as an imperative right the payment for external consultants, in practice, the agreements that do not include a clause that allows workers' representatives to appoint an advisor are in the minority; only three agreements (Campofrío, Ferroatlántica and Roca) do not mention this issue.

In the rest, they generally recognise the right of the parties to name at least one external consultant, provided management is informed in advance, with the management assuming the economic cost. However, some agreements, such as that of Altadis, have gone even further, stipulating that the council shall have a maximum budget of 18,000 euros for experts. Up to four consultants may be appointed, two for Spain and two for France.

Santander's agreement is also interesting, as it provides for the appointment of an external advisor, but also includes the possibility of naming up to three internal consultants from the national representatives, who would participate in the EWC meetings but would not be able to vote.

Generally speaking, expenses arising from EWC activity, such as expenses for meals, daily allowances, etc., are dealt with similarly in the different agreements. The common practice is for the company to assume the costs of transportation and lodging. With regard

\footnotetext{
${ }^{46}$ The Abertis, Santander and Saica agreements limit translation to three languages. The Roca agreement mentions translation to the languages that are strictly necessary. The IAG agreement establishes English as the main language, but with the possibility of translating into Spanish when necessary.
} 
to other expenses, several agreements state they will cover reasonable expenses. This is a nonspecific legal concept that will allow all ordinary expenses for the correct functioning of the EWC to be covered by the company. The AXA agreement is the only one that differs from this general criterion. The parties set an annual budget of $€ 85,000$ to cover the costs associated with the EWC. ${ }^{47}$

Although not in the majority, ten agreements recognise the right of the workers' representatives to have training paid for by company management. ${ }^{48}$ This training may be on legal/ economic knowledge, languages, or both. The management of a transnational company entails highly complex issues that may not be easy to understand or master for the average representative. For example, dealing with a transnational business group's financial statements may require a high level of accounting knowledge that perhaps not all representatives possess. To this we must add a lack of knowledge of the company's native language, which can make the task of the workers' representative even more difficult. Therefore, including regulations regarding training should be considered a good practice and it should be included in other agreements.

j) EWC meetings: The regulation of the EWC meetings is also an important issue for the effectiveness of the worker representation bodies. If more meetings are held and workers' representatives are more involved, workers will have greater control and the information and consultation work will be more effective.

Across the board, the negotiators have opted for annual council meetings; the most sparing agreements have chosen to hold a single annual meeting, while others have chosen two sessions. ${ }^{49}$ In some cases, additionally, the agreement includes the possibility of holding an extraordinary meeting if the parties so agree under extraordinary circumstances..$^{50}$ As a mechanism for increasing flexibility regarding the necessary agreement between the parties in order to call an extraordinary EWC meeting, some instruments have opted for allowing the workers' representatives to meet without the presence of company management when the latter do not consider an extraordinary meeting to be necessary. ${ }^{51}$

A minority of agreements have set the interval in which a meeting must be held between the workers' representation and the company management. This requirement certainly eliminates the uncertainty regarding the meeting and makes it impossible for the party calling

\footnotetext{
${ }^{47}$ Article 5.7 of the Agreement stipulates: "The G.E.W.C. Secretariat shall have an annual budget of $€ 85,000$ to cover all costs (excluding contributions covering $50 \%$ of the compensation of the Secretary's assistant) relating to the Secretariat's operations and meetings (meetings, travel and interpretation expenses, committee expenses and experts)[...]".

${ }^{48}$ The agreements that expressly recognise training to be paid for by company management are: Prosegur, Abertis, Axa, Altadis, GE Power, Amadeus, Gestamp, Ferroatlántica, Schereiber foods and IAG Group.

${ }^{49}$ The Repsol, GE Power, Praxair, Saica, Santander, BBVA, Roca, Abertis, Prosegur and Schreiber Foods agreements call for a single meeting.

${ }^{50}$ In this sense, art. 4.3 of the Repsol Agreement “[...] Exceptionally, a meeting separate from the annual meeting may be held, provided that Management and workers' representatives agree that it is necessary." and art. 4.b) of the Saica group Agreement "Exceptionally, a meeting other than the annual meeting may be held, provided that both parties agree that there is an objective need to hold one. This extraordinary meeting may be held either during the European Works Council plenary session or between the Group Management and the Select Committee, as circumstances dictate." The Roca group Agreement goes a step further and allows for an extraordinary meeting whenever one of the parties requests it, art. 6.4.1.2: "The Forum, to be convened by its Chairman at the venue appointed by the latter, shall meet once per year and on an extraordinary basis whenever one of the parties, Management or Coordinators [the workers' representatives name three coordinators as permanent spokespeople with the company management], so request should exceptional circumstances arise. [...]." Some agreements, such as that of the Praxair Group, have established that extraordinary meetings may be held via teleconference, and that in-person meetings may then be held to follow up on the subject that originated in the extraordinary teleconference meeting, art. 6.8: "In the case of Exceptional Circumstances that are not included on the agenda for the annual meeting, the Management Representatives will communicate with Employee Representatives. This communication, Information and Consultation will be effective either through a meeting of the Employee Representatives or by a teleconference call. In the case of a teleconference each party will have the right to decide whether a physical follow-up meeting is required."

51 " [...] Another meeting may be held by prior agreement of the parties, if circumstances exist that make it advisable. If no such meeting is envisaged, the trade union party may, after informing the Central Management, hold a second annual meeting in Madrid attended only by its members. [...]." This clause appears literally in art. 3 of the BBVA group agreement and in art. 3 of the Santander Group agreement.
} 
the meeting, usually the management or the management after having consulted the workers' representatives, to do so when it is more convenient to their interests. ${ }^{52}$

The Abertis, Altadis and AXA group agreements provide improvements on the general regulations regarding the annual meetings mentioned above. The first states that the EWC will meet yearly with company management and that management must inform the Select Committee every semester and the EWC every year of all operational plans that may have an effect on group companies and their staff. Furthermore, in the event of exceptional circumstances, company management may call a meeting with the Select Committee or, depending on the importance of the issue to be discussed, the entire EWC. ${ }^{53}$ The Altadis Agreement establishes two annual meetings, one each semester. ${ }^{54}$ Finally, the AXA Group stipulates two annual meetings and the possibility of the workers' representatives requesting an extraordinary meeting in the event of exceptional circumstances. Company management will decide if this additional meeting should be held, explaining its reasoning in writing. Additionally, the agreement includes the possibility of holding an annual preparatory meeting in which the council members would visit the different States in which the group operates..$^{55}$

Finally, just one agreement, that of GE Power, does not include the possibility of holding preparatory meetings for the delegation of the workers' representatives without the presence of company management. All the other agreements, both those using the French and German models, establish that the workers' representatives can meet behind closed doors immediately before meeting with central management in order to prepare for the meeting, agree upon stances, or answer questions before sharing information.

Three practices are exceptions to the general rule, those of the Abertis, AXA and Schreiber Foods groups, which allow for the holding of a private meeting attended by the representatives of the workers. The former includes the possibility of the workers' representation holding a private meeting after the meeting with company management. This is an interesting option, as it allows the workers' delegation to evaluate the objectives achieved during the meeting with management. The second exception is that set out in the AXA group's agreement. In this case, in addition to the preparatory meetings of the workers' representation before the meeting, a preparatory visit is established. This visit is not to be immediately before the meeting with management, but consists of a meeting during the quarter prior to the meeting with management. This visit allows for representative training and to promote knowledge of the reality of the company in the country in which the meeting will be held. ${ }^{56}$

${ }^{52}$ Art. 5 Prosegur Group Agreement: "The European Works Council will meet annually in the last quarter of the year on a call notice agreed by the Company, chair and secretary, who together will act as a standing point of contact"; art. 3 of the BBVA Group Agreement: "During the first four months of the year, the Works Council shall hold an annual meeting [...]"; art. 6 of the Amadeus agreement states that the annual meeting will be held in November; art. 3.1 of the Tafisa agreement stipulates that the meeting will be held on the second Wednesday of October every year.

${ }^{53}$ Abertis Agreement art. 6.1: "The meeting shall be convened by the Central Management at least 1 (one) month in advance, hereby the notice convening the meeting shall be accompanied by a report on the development and prospects of the activities of the Abertis group [...]. The Central Management shall inform the Select Committee on a semi-annual basis, and the EWC on an annual basis"; art. 6.2.d) "When exceptional circumstances occur or when decisions may be taken that have a considerable effect on the interests of the workers (whereby, such an exceptional situation includes, but is not limited to, relocation, closure of companies or collective redundancies of a transnational nature), which does not augur well for the annual meeting of the EWC, the Select Committee shall be entitled to be informed. The Select Committee shall moreover be entitled to meet, with the Central Management or any other more appropriate management, with prior request to the Central Management, so as to be informed and consulted about the aforementioned circumstances of an exceptional nature or which have a considerable effect on the employees. [...]"; and art. 8 "If situations of an exceptional nature arise (as defined in Section 6.2.d) which can have important consequences for the interests of the employees, the Central Management shall initiate immediately a process of information and consultation for the EWC on the matter. An extraordinary meeting of the EWC shall accordingly be convened within 1 (one) month, in accordance with the procedure provided under Section 6.8 of this Agreement".

${ }^{54}$ Art. 5 of the Altadis Agreement.

${ }^{55}$ The AXA group Committee establishes the existence of an EWC chair, composed of members of company management and of workers. Art. 5.2 of the Agreement.

${ }^{56}$ The AXA group agreement contains some of the most exhaustive regulations regarding meetings of the workers' representation. It includes monthly meetings of the committee chair, which is essentially the select committee; preparatory meetings 
k) Confidentiality: All of the agreements contain specific provisions regarding the confidentiality obligations of the committee members. Additionally, several agreements contain provisions in which they explicitly state that the EWC's work will in no way limit the company's decisionmaking power. In other words, the agreements expressly recognise that the responsibility to provide information and consultation does not imply a responsibility to reach agreements.

Both provisions were strongly promoted by Community business organisations, distrusting the limiting effects that the EWCs could have on their actions.

This obligation of confidentiality will persist even after the members' term on the committee ends. ${ }^{57}$

1) Topics subject to information and consultation: Directive 2009/38/EC innovated with regard to earlier regulation and included a definition of the transnational issues with regard to which the EWC could be informed and consulted. The definition was very generic ${ }^{58}$ but was set up as a minimum that could be improved upon through negotiation between the parties. However, the parties have not broadened the scope of the issues that could be the topic of a negotiation in the framework of the EWC. In fact, some agreements expressly limit this possibility. ${ }^{59}$

The Directive states that transnational information and consultation with the EWC shall refer especially to the Community-scale company or group of companies' structure, economic and financial state, probable evolution of activity, production and sales, as well as the probable evolution of employment, investments, substantial changes that affect the organisation, the implementation of new work or production methods, production moves, mergers, reduction in size or closures of companies, establishments, or important parts thereof, and collective redundancies. This list, which does not contain a numerus clausus, has been included without hardly any modification in the majority of the Spanish agreements. Only a minority of the agreements have created a somewhat more specific list, although in practice this does not change much, as in no case is it a closed list. ${ }^{60}$ It should be mentioned that not all of the matters listed above, or those included in each agreement, shall be handled by the EWC, as they must also be matters of transnational scope. Otherwise, they may not be dealt with in the framework of the EWC.

In conclusion, if we had to describe the typical Spanish EWC, we could say that it follows the French model and has a small number of members and, therefore, differs from the habitual practices regarding the quantitative composition of workers' representation in Spain. EWC members are distributed proportionally among all States in which the undertaking or group of undertakings operates; the Spanish representatives, the result of this proportional distribution, are elected from among the Spanish representatives on workers' committees or union representatives and must meet the requirements set out in article 69.2 of the Workers' Statute in order to be selected. The same requirements and formula will be used to designate the substitutes for the main representatives.

for the EWC plenary meetings; two annual plenary meetings, which are held alternately in the company's headquarters and in the different States in which the group has companies; extraordinary meetings in the event of circumstances that greatly affect the interests and rights of the workforce; and finally, a preparatory meeting before meetings that take place outside the country where headquarters is located, so that representatives can better understand the company's productive reality in that country.

${ }^{57}$ Art. 8 Directives 94/45 and 2009/38/EC, art. 22 of Law 10/1997.

${ }^{58}$ Article 1.4 Directive 2009/38/EC: "Matters shall be considered to be transnational where they concern the Community-scale undertaking or Community-scale group of undertakings as a whole, or at least two undertakings or establishments of the undertaking or group situated in two different Member States".

${ }^{59}$ Along these lines, for example, the Prosegur agreement expressly states that the EWC shall not deal with matters that affect a single State or States outside of Europe. The BBVA agreement stipulates that matters that affect a single State must be resolved within the national structures and procedures. Finally, the Santander agreement states that the EWC shall not have authority over nor shall it deal with local or national matters subject to national legislation or Collective Agreements, nor over the rights of the Works Councils or union delegates, over co-management, compensation, work hours, wages or other benefits, nor any other matter regarding individual employees, as all of these matters should be dealt with within the structures, procedures and regulations that apply in each Group Company.

${ }^{60} \mathrm{In}$ this regard, the Prosegur agreement includes health and the group's environmental policy as transnational matters. The Abertis group includes work hours and health. The Saica group includes the group's strategic plan. Finally, GE Power includes environmental policy and training. 
Despite the low number of representatives, the Spanish EWC prototype has a select committee so as to facilitate the effectiveness of its activity. The ordinary operational expenses of the select committee, as well as the plenary session of the EWC will be covered by central management. Ordinary expenses include simultaneous interpretation in meetings and translation of working documents, expenses for travel and daily stipends for the workers' representatives at the annual EWC meeting and any extraordinary meetings that are called, as well as the costs of an external consultant, who may attend said meetings but may not vote.

EWC information and consultation shall be limited exclusively to transnational matters that affect the group or company. The workers' representatives are subject to confidentiality.

\section{Conclusion}

The constitution of EWCs in Spain has met with modest success. Only 17.8\% of companies that could have established an EWC have effectively done so. Therefore, we are far from the European average, where half of companies have already implemented mechanisms to inform and consult with their workers.

Additionally, these agreements can hardly be called innovative; in general, they limit themselves to following the subsidiary scheme established in Community Directives and in Law 10/1997. Almost all of the texts are succinct, and in some cases only formally constitute the EWC without implementing any provisions beyond its establishment.

The lack of ambition in transnational bargaining between the parties can be evidenced by the fact that no agreement has tried to make use of the EWC as a space for supranational bargaining.

Thus, no agreement has chosen to configure the European area as a negotiation unit where the company's work conditions can be discussed and agreed upon. In fact, it is just the opposite; some agreements expressly prohibit this possibility, as in the Saica Group agreement. ${ }^{61}$ The Community Directives and their national implementations only set subsidiary regulations for the parties, but said regulations could be improved upon or regulated in a different manner. Therefore, company management and workers' representatives could have taken advantage of the negotiation for these agreements to implement Community-scale negotiation mechanisms, however rudimentary.

The agreements have also not included States outside of the European Union. Nothing prevents the negotiating parties from agreeing to a scope of application that extends beyond European borders. In this regard, Directive 94/45 could have been used to constitute information and consultation procedures in consonance with the company or group of companies' real structure. That is, information and consultation procedures or EWCs could have been established that included all States in which the company or group of companies operated, regardless of whether they were European or not.

A less ambitious, although more reasonable option would have been to take into consideration at least those States that are candidates for European Union membership. However, not even this step was taken by the negotiation commissions. It is true that the European Union is not expected to grow in the short term. ${ }^{62}$ However, in the past, at times when it was easier to envision the incorporation of certain States, the negotiators did not choose to include a foresighted, expansive regulation. Along these lines, for example, in 2007 Roca had to adapt its EWC to the incorporation of Bulgaria and Romania to the EU, which had occurred that same year.

In conclusion, there is still room to encourage and incentivise Spanish companies to develop Community-scale information and consultation mechanisms. Without a doubt, the most interesting possibility would be for social agents to take advantage of the transnational bargaining made possible by an EWC in order to agree upon a common minimum baseline for the work conditions applicable in their

\footnotetext{
${ }^{61}$ Article 1 of the Saica group's EWC constitution Agreement states: "The SAICA European Works Council is a body that brings together the Group's Management with its employee representatives in European Union Member States where the Group has companies in whose capital it has a 51\% stake or more. [...] Under no circumstances shall the SAICA European Works Council act as a negotiating body".

${ }^{62}$ Candidate States are: Albania, the Former Yugoslav Republic of Macedonia, Iceland, Montenegro, Serbia and Turkey. Bosnia and Herzegovina and Kosovo are recognised as potential candidates.
} 
workplaces. However, a first and commendable step would be for negotiators, instead of choosing an agreement model that limits itself to transcribing the content of the Law and Directives, to choose to incorporate and develop the more progressive practices mentioned here within the agreements analysed - those experiences which have been highlighted by this study as the most inspirational and ambitious in constructing the most mature and effective transnational model of worker representation. 